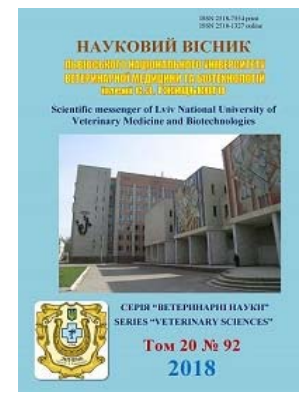

\author{
Науковий вісник Дьвівського національного університету \\ ветеринарної медицини та біотехнологій імені С.3. Гжицького
}

\author{
Scientific Messenger of Lviv National University \\ of Veterinary Medicine and Biotechnologies
}

\title{
Express methods for determining the processing of meat by disinfectants during storage and sale
}

\author{
N.M. Bogatko' ${ }^{1}$ I.V. Yatsenko ${ }^{2}$, T.I. Fotina ${ }^{3}$ \\ ${ }^{1}$ Bilotserkivsky National Agrarian University, Bila Tserkva, Ukraine \\ ${ }^{2}$ Kharkiv NDI of the court examinations im. prof. M.S. Bokariusa, Kharkiv, Ukraine \\ ${ }^{3}$ Sumy National Agrarian University, Sumy, Ukraine
}

Article info

Received 09.10.2018

Received in revised form 12.11.2018

Accepted 13.11.2018

Bila Tserkva National Agrarian University, Pl. Soborna 8/1, Bila Tserkva, Kyiv region, 09117, Ukraine.

E-mail:nadiyabogatko@ukr.net

Kharkiv NDI of the court examinations im. prof. M.S. Bokariusa, Zolochivskaya Str., 8 , Kharkiv, 61177, Ukraine. Tel.: +38-067-186-06-65 E-mail: yacenko-1971@ukr.net

Sumy National Agrarian University, Gerasim Kondratyev Str., 160, Sumy, 40000, Ukraine.
Bogatko, N.M., Yatsenko, I.V., \& Fotina, T.I. (2018). Express methods for determining the processing of meat by disinfectants during storage and sale. Scientific Messenger of Lviv National University of Veterinary Medicine and Biotechnologies, 20(92), 24-28. doi: 10.32718/nvlvet9205

\begin{abstract}
The need to improve the control of meat slaughter animals and poultry in their rigging to develop modern express methods that have credibility in the indicators within and 99,4 to $99.9 \%$, and can be used along with other methods to determine their quality and safety in the manufacturing laboratory facilities for meat processing, slaughtering companies and companies with sales and storage of meat (supermarkets, wholesale warehouses, refrigerators and the like), in the state laboratories of veterinary medicine and in laboratories of veterinary-sanitary examination of agro-industrial markets. Despite the fact that the responsibility for the safety and quality of food of animal origin is entrusted to the manufacturer, the protection of consumer health is always under control of the state. To ensure consumers receive safe and high quality meat need to develop new rapid methods for their adequate control. Especially relevant are the research directions for the development of rapid methods to objectively assess the safety and quality of meat of slaughtered animals and poultry during storage, and the implementation or use for the production of meat products. In stores, supermarkets, wholesale bases, the agricultural markets during the implementation of the meat of slaughtered animals and poultry it is often possible to detect the adulteration of meat for the handling of formalin, chlorine, hydrogen peroxide, acetic acid, potassium permanganate for long-term storage and eliminate the signs of damage. Therefore, we have performed experimental studies and developed rapid methods to identify this type of fraud. Developed rapid methods for the determination of adulteration of meat of slaughter animals and poultry with formalin, chlorine, hydrogen peroxide, acetic acid, potassium permanganate are simple to implement and their results specific quality indicators. Therefore, these rapid methods are available us along with other methods for determining the quality and safety of meat slaughtered animals and poultry (determination of organoleptic, the content of amino-ammoniac nitrogen, hydrogen sulfide, ammonia, $\mathrm{pH}$, etc). These methods can be used in determining the safety and quality of meat of slaughtered animals and poultry during storage, and the implementation of laboratories at the facilities of meat processing, supermarkets, wholesale bases, in government veterinary laboratories and laboratories of veterinary-sanitary examination of agro-industrial markets.
\end{abstract}

Key words: forensic examination of food products, express research methods, pork, beef, lamb, goat meat, poultry meat.

\section{Експрес-методи виявлення обробки м'яса дезінфікуючими засобами під час зберігання та реалізації}

\author{
Н.М. Богатко ${ }^{1}$, I.В. Яценко ${ }^{2}$, Т.I. Фотіна ${ }^{3}$ \\ ${ }^{1}$ Білочерківський національний аграрний університет, м. Біла Церква, Україна \\ ${ }^{2}$ Харківський НДІ судових експертиз ім. засл. проф. М.С. Бокаріуса, м. Харків, Украӥна \\ ${ }^{3}$ Сумський національний аграрний університет, м. Суми, Украӥна
}

Розроблені експрес-методи виявлення обробки м'яса ссавців та птиці дезінфікуючими засобами (формаліном, хлором, пероксидом водню, оцтовою кислотою) з метою приховування ознак його псування. Ці методи можуть бути використані поряд з 
іншими методами під час проведення судової експертизи необроблених харчових продуктів, зокрема м'яса. Вірогідність результатів визначення становить 99,4-99,9\%. Для контролю якості й безпечності м'яса забійних ссавців та птиці під час їх зберігання й реалізації пропонується застосовувати розроблені експрес-методи у виробничих лабораторіях потужностей із переробки м'яса, забійних підприємствах та підприємствах із реалізації та зберігання м'яса, у державних лабораторіях ветеринарної медицини та в лабораторіях ветеринарно-санітарної експертизи на агропродовольчих ринках, а також під час проведення судової експертизи харчових продуктів, зокрема м'яса забійних ссавців та птиці

Ключові слова: судова експертиза харчових продуктів, експрес-методи дослідження, свинина, яловичина, баранина, козлятина, м'ясо птиці.

\section{Вступ}

Незважаючи на те, що відповідальність за безпечність та якість харчових продуктів тваринного походження покладена на виробника, захист здоров’я споживача завжди залишається під контролем держави (Pro veterynarnu medytsynu, 2002). Державна служба України з питань безпечності харчових продуктів та захисту споживачів, основним завданням якої $є$ реалізація державної політики у галузі ветеринарної медицини, сферах безпечності та окремих показників якості харчових продуктів, ідентифікації та реєстрації ссавців, санітарного законодавства, метрологічного нагляду, ринкового нагляду в межах сфери своєї відповідальності, державного контролю за додержанням законодавства про захист прав споживачів і реклами в цій сфері, повинна виконувати вимоги нової Європейської регламентації щодо харчових продуктів, Комісії Кодексу Аліментаріус, ВОО3, основних положень торгових Угод SPS і TBT та організовувати свою роботу на основі оцінки ризиків із санітарної безпеки харчових продуктів (Pro osnovni pryntsypy ta vymohy..., 2004; Rehlament № 852/2004; Rehlament № 854/2004).

Для забезпечення отримання споживачами безпечної та якісної м'ясної сировини необхідно розробляти нові експресні методи щодо їх належного контролю. Особливо актуальними є напрями досліджень щодо розробки експресних методів, які дають змогу об'єктивно оцінити безпечність та якість м'яса забійної худоби та птиці під час зберігання та реалізації або використання для виробництва м'ясопродуктів (Systemy upravlinnia bezpechnistiu kharchovykh produktiv, 2007).

У світовій науці і практиці застосовуються найчутливіші методи визначення безпечності та якості м'ясної сировини. У магазинах, супермаркетах, оптових базах, на агропромислових ринках під час реалізації м'яса забійних ссавців та птиці дуже часто можна виявити оброблення м'яса формаліном, хлором, пероксидом водню, оцтовою кислотою, калієм перманганатом для усунення ознак псування та подовження терміну його зберігання. Тому нами були проведені експериментальні дослідження для розробки експресних методів виявлення зазначених ксенобіотиків (Page et al., 2001; Reichert, 2006; Bohatko et al., 2015).

Завданням дослідження було провести контроль якості м'яса забійних ссавців та розробити експресметоди виявлення обробки м'яса худоби та птиці дезінфікуючими засобами 3 метою приховування ознак його псування та подовження термінів зберігання в торговельній мережі.

\section{Матеріал та методи досліджень}

Для дослідження використовували проби м'яса забійних ссавців та птиці: свинини, яловичини, баранини, козлятини, а також тушки м'яса птиці, що були доставлені на потужності з переробки м'яса Київської області, а також реалізувались на агропромислових ринках, супермаркетах та зберігалися на оптових базах.

Попередньо проби м'яса забійних ссавців та птиці були досліджені органолептично (колір, запах, консистенція, проба варіння тощо) (Mjaso, 1979) та в комплексі з біохімічними дослідженнями щодо визначення ступеня свіжості та визначення м'яса, яке отримане від здорових ссавців і птиці (Mjaso, 1978; Pravyla peredzabiinoho veterynarnoho ohliadu tvaryn..., 2002).

Також було розроблено експресні методи виявлення обробки м'яса ссавців та птиці дезінфікуючими засобами (формаліном, хлором, пероксидом водню, оцтовою кислотою, калієм перманганатом) 3 метою приховування ознак його псування та подовження терміну його реалізації.

\section{Результати та їх обговорення}

За органолептичними, біохімічними показниками м'ясо забійних ссавців та м'ясо птиці відповідало свіжому ступеню та було отримане від клінічно здорових ссавців і птиці.

Для визначення фальсифікації м'яса забійних ссавців та птиці за обробки їх розчином формаліну, хлору, пероксидом водню, оцтовою кислотою були розробленні експресні методи.

Суть методу виявлення зазначених дезінфектантів у м'ясі забійних ссавців та птиці за обробки їх формаліном полягає у використанні суміші концентрованих азотної та сірчаної кислот та утворенні жовто-бурого або фіолетово-червоного кольору. Завдання розробленого експрес-методу вирішувалася тим, що на поверхню м'язів свинини, яловичини, баранини, козлятини, та на тушку птиці площею 2,5×3,0 см наносили кілька крапель суміші концентрованих азотної та сірчаної кислот у співвідношенні 1:25 і через 46 хвилин встановлювали зміну кольору від жовтобурого до фіолетово-червоного.

Стабільність показників за інтенсивністю кольору під час встановлення обробки м'яса забійних ссавців та птиці формаліном становить 99,4\%. Також значно вірогідніші дані - у 98,7-99,0\% отримані порівняно 3 методом визначення вмісту аміно-аміачного азоту та у 98,9-99,2\% -3 методом визначення вмісту сірководню в м'ясі. 
Ми виявляли обробку м'яса забійних ссавців та птиці формаліном за інтенсивністю кольору на 42 пробах: 8 пробах свинини; 9 пробах яловичини,
6 пробах баранини; 5 пробах козлятини; 14 пробах тушок птиці. Результати досліджень наведені в таблиці 1.

\section{Таблиця 1}

Виявлення м'яса, обробленого формаліном за інтенсивністю кольору

\begin{tabular}{lclcc}
\hline \multicolumn{1}{c}{ Види м'яса } & $\begin{array}{c}\text { Кількість } \\
\text { проб }\end{array}$ & $\begin{array}{c}\text { Показники інтенсивності кольору за } \\
\text { оброблення м'яса формаліном }\end{array}$ & $\begin{array}{c}\text { Кількість } \\
\text { проб }\end{array}$ & $\begin{array}{c}\text { Показники інтенсивності кольору } \\
\text { за відсутності оброблення м'яса } \\
\text { формаліном }\end{array}$ \\
\hline Свинина, $\mathrm{n}=8$ & 2 & Наявність фіолетово-червоного кольору & 6 & Наявність жовто-бурого кольору \\
Яловичина, $\mathrm{n}=9$ & 2 & Наявність фіолетово-червоного кольору & 7 & Наявність жовто-бурого кольору \\
Баранина, $\mathrm{n}=6$ & 1 & Наявність фіолетово-червоного кольору & 5 & Наявність жовто-бурого кольору \\
Козлятина, $\mathrm{n}=5$ & 2 & Наявність фіолетово-червоного кольору & 3 & Наявність жовто-бурого кольору \\
Тушки птиці, $\mathrm{n}=14$ & 9 & Наявність фіолетово-червоного кольору & 5 & Наявність жовто-бурого кольору \\
\hline
\end{tabular}

Проведеними дослідженнями встановлено, що найбільша кількість тушок птиці була оброблена розчином формаліну, що визначалася за інтенсивністю фіолетово-червоного кольору м'яса.

Суть методу виявлення обробки м'яса забійних ссавців та птиці хлором полягає у встановленні наявності або відсутності синього кольору під час послідовного додавання до м'ясо-водної витяжки розчинів йодистого калію, водорозчинного крохмалю та концентрованої хлорводневої кислоти.

Завдання розробленого експрес-методу вирішувалася тим, що поверхню свинини, яловичини, баранини, козлятини, тушки птиці зрізували ножицями у кількості 2,0-2,1 г, подрібнювали, кількісно переносили у конічну колбу місткістю $25 \mathrm{~cm}^{3}$, додавали 4,0 $4,1 \mathrm{~cm}^{3}$ дистильованої води і настоювали упродовж 510 хв. Приготовлену м'ясо-водну витяжку в співвідношенні 1:2 фільтрували крізь паперовий беззольний фільтр. У пробірку градуйованою піпеткою вносили профільтровану м'ясо-водну витяжку у кількості 2,0 $2,1 \mathrm{~cm}^{3}$ і додавали послідовно реактиви: $0,2-0,3 \mathrm{~cm}^{3}$ розчину йодистого калію 3 масовою концентрацією $5,0 \%$ та $0,2-0,3 \mathrm{~cm}^{3}$ розчину водорозчинного крохмалю 3 масовою концентрацією 2,0\%, також 2,0-2,1 $\mathrm{cm}^{3}$ концентрованої хлорводневої кислоти. Вміст пробірки збовтували, ставили у штатив на 1-4 хв і спостерігали за зміною кольору. За обробки м'яса забійних ссавців та птиці хлором уміст пробірки забарвлювався у синій колір, а за відсутності оброблення колір був безбарвним.

Стабільність показників інтенсивності кольору для виявлення оброблення м'яса забійних ссавців та птиці хлором становила 99,5\%. Також вірогідніші дані - у 98,1-99,0\% були отримані порівняно 3 методом визначення вмісту аміно-аміачного азоту в м'ясі та у 98,5-99,3\% - з методом визначення вмісту сірководню в м'ясі.

Ми виявляли обробку м'яса забійних ссавців та птиці хлором за інтенсивністю кольору на 36 пробах: 8 пробах свинини; 9 пробах яловичини, 5 пробах баранини; 4 пробах козлятини; 10 пробах тушок птиці. Результати досліджень наведено в таблиці 2.

\section{Таблиця 2}

Виявлення оброблення м'яса хлором за інтенсивністю кольору

\begin{tabular}{|c|c|c|c|c|}
\hline Види м'яса & $\begin{array}{l}\text { Кількість } \\
\text { проб }\end{array}$ & $\begin{array}{c}\text { Показники інтенсивності кольору за } \\
\text { оброблення м’яса хлором }\end{array}$ & $\begin{array}{l}\text { Кількість } \\
\text { проб }\end{array}$ & $\begin{array}{c}\text { Показники інтенсивності кольору } \\
\text { за відсутності оброблення м’яса } \\
\text { хлором }\end{array}$ \\
\hline Свинина, $\mathrm{n}=8$ & 1 & $\begin{array}{l}\text { Наявність синього кольору } \\
\text { (позитивна реакція) }\end{array}$ & 7 & $\begin{array}{l}\text { Відсутність синього кольору } \\
\text { (негативна реакція) }\end{array}$ \\
\hline Яловичина, n = 9 & & $\begin{array}{l}\text { Наявність синього кольору } \\
\text { (позитивна реакція) }\end{array}$ & 7 & $\begin{array}{l}\text { Відсутність синього кольору } \\
\text { (негативна реакція) }\end{array}$ \\
\hline Баранина, $\mathrm{n}=5$ & 1 & $\begin{array}{l}\text { Наявність синього кольору } \\
\text { (позитивна реакція) }\end{array}$ & 4 & $\begin{array}{l}\text { Відсутність синього кольору } \\
\text { (негативна реакція) }\end{array}$ \\
\hline Козлятина, n = 4 & 1 & $\begin{array}{l}\text { Наявність синього кольору } \\
\text { (позитивна реакція) }\end{array}$ & 3 & $\begin{array}{l}\text { Відсутність синього кольору } \\
\text { (негативна реакція) }\end{array}$ \\
\hline Тушки птиці, $\mathrm{n}=10$ & 7 & $\begin{array}{l}\text { Наявність синього кольору } \\
\text { (позитивна реакція) }\end{array}$ & 3 & $\begin{array}{l}\text { Відсутність синього кольору } \\
\text { (негативна реакція) }\end{array}$ \\
\hline
\end{tabular}

Проведеними дослідженнями визначено, що найбільша кількість тушок птиці була оброблена хлором, що відзначалось за інтенсивністю синього кольору в м'ясо-водневій витяжці.

Суть методу визначення обробки м'яса забійних ссавців та птиці за пероксидом водню полягає у встановленні наявності або відсутності світло-синього кольору 3 використанням концентрованої сірчаної кислоти та йодисто-калієвого крохмалю.

Завдання розробленого експрес-методу вирішувалася тим, що на поверхню свинини, яловичини, баранини, козлятини та на тушку птиці площею розміром $1,5 \times 2,0$ см наносили $0,5-0,6 \mathrm{~cm}^{3}$ концентрованої сірчаної кислоти та $0,2-0,4 \mathrm{~cm}^{3}$ йодисто-калієвого крохмалю і через 1-5 хв встановлювали наявність або 
відсутність забарвлення поверхні м'яса у світло-синій колір.

Стабільність показників інтенсивності кольору під час визначення оброблення м'яса забійних ссавців та птиці пероксидом водню становить 99,6\%. Також вірогідніші дані були отримані - у 98,9-99,2\% порівняно $з$ методом визначення вмісту аміно-аміачного азоту в м'ясі та у 98,2-99,1\% - з методом визначення вмісту сірководню в м'ясі.

Ми визначили оброблення м'яса забійних ссавців та птиці пероксидом водню за інтенсивністю кольору на 38 пробах: 10 пробах свинини; 10 пробах яловичини, 5 пробах баранини; 4 пробах козлятини; 9 пробах тушок птиці. Результати дослідження наведені в таблиці 3.

\section{Таблиця 3}

Виявлення оброблення м'яса пероксидом водню за інтенсивністю кольору

\begin{tabular}{|c|c|c|c|c|}
\hline Види м’яса & $\begin{array}{l}\text { Кількість } \\
\text { проб }\end{array}$ & $\begin{array}{l}\text { Показники інтенсивності кольору за } \\
\text { оброблення м'яса пероксидом водню }\end{array}$ & $\begin{array}{l}\text { Кількість } \\
\text { проб }\end{array}$ & $\begin{array}{c}\text { Показники інтенсивності кольору за } \\
\text { відсутності оброблення м'яса перок- } \\
\text { сидом водню }\end{array}$ \\
\hline Свинина, $\mathrm{n}=10$ & 3 & $\begin{array}{l}\text { Наявність світло-синього кольору } \\
\text { (позитивна реакція) }\end{array}$ & 7 & $\begin{array}{l}\text { Відсутність світло-синього кольору } \\
\text { (негативна реакція) }\end{array}$ \\
\hline Яловичина $\mathrm{n}=10$ & 1 & $\begin{array}{l}\text { Наявність світло-синього кольору } \\
\text { (позитивна реакція) }\end{array}$ & 9 & $\begin{array}{l}\text { Відсутність світло-синього кольору } \\
\text { (негативна реакція) }\end{array}$ \\
\hline Баранина, $\mathrm{n}=5$ & 2 & $\begin{array}{l}\text { Наявність світло-синього кольору } \\
\text { (позитивна реакція) }\end{array}$ & 3 & $\begin{array}{l}\text { Відсутність світло-синього кольору } \\
\text { (негативна реакція) }\end{array}$ \\
\hline Козлятина, $\mathrm{n}=4$ & 0 & $\begin{array}{l}\text { Наявність світло-синього кольору } \\
\text { (позитивна реакція) }\end{array}$ & 4 & $\begin{array}{l}\text { Відсутність світло-синього кольору } \\
\text { (негативна реакція) }\end{array}$ \\
\hline Тушки птиці, n = 9 & 5 & $\begin{array}{l}\text { Наявність світло-синього кольору } \\
\text { (позитивна реакція) }\end{array}$ & 4 & $\begin{array}{l}\text { Відсутність світло-синього кольору } \\
\text { (негативна реакція) }\end{array}$ \\
\hline
\end{tabular}

Проведеними дослідженнями визначено, що найбільша кількість тушок птиці була оброблена пероксидом водню, що спостерігалася за інтенсивністю світло-синього кольору у м'ясній витяжці.

Суть методу визначення оброблення м'яса забійних ссавців та птиці за оцтовою кислотою полягає у встановленні наявності або відсутності рожевого кольору 3 використанням розчину натрію гідроксиду 3 масовою концентрацією 0,1 моль/дм ${ }^{3}$ та індикатору спиртового розчину фенолфталеїну з масовою концентрацією $1 \%$.

Завдання розробленого експрес-методу вирішувалася тим, що на поверхню свинини, яловичини, баранини, козлятини та на тушку птиці площею розміром $2,0 \times 2,5$ см наносили градуйованою піпеткою 0,5$0,6 \mathrm{~cm}^{3}$ розчину натрію гідроксиду 3 масовою концентрацією 0,1 моль/дм ${ }^{3}$ та 0,1-0,2 см$^{3}$ індикатору спир- тового розчину фенолфталеїну з масовою концентрацією $1 \%$ і через 0,5-1,0 хв встановлювали наявність або відсутність рожевого кольору на поверхні м'яса.

Стабільність показників інтенсивності кольору під час виявлення оброблення м'яса забійних ссавців та птиці оцтовою кислотою становила 99,8\%. Також вірогідніші дані - у 98,4-99,5\% були отримані порівняно - 3 методом визначення вмісту аміно-аміачного азоту в м'ясі та у 98,8-99,6\% з методом визначення вмісту сірководню в м'ясі.

Ми виявили обробку м'яса забійних ссавців та птиці оцтовою кислотою за інтенсивністю кольору на 42 пробах: 12 пробах свинини; 10 пробах яловичини, 5 пробах баранини; 4 пробах козлятини; 11 пробах тушок птиці. Результати проведених досліджень наведені в таблиці 4.

\section{Таблиця 4}

Виявлення обробки м'яса оцтовою кислотою за інтенсивністю кольору

\begin{tabular}{lclcc}
\hline \multicolumn{1}{c}{ Види м'яса } & $\begin{array}{c}\text { Кіль- } \\
\text { кість } \\
\text { проб }\end{array}$ & $\begin{array}{c}\text { Показники інтенсивності кольору за } \\
\text { обробки м’яса оцтовою кислотою } \\
\text { (позитивна реакція) }\end{array}$ & $\begin{array}{c}\text { Кіль- } \\
\text { кість } \\
\text { проб }\end{array}$ & $\begin{array}{c}\text { Показники інтенсивності кольору } \\
\text { за відсутності обробки м’яса оцто- } \\
\text { вою кислотою (негативна реакція) }\end{array}$ \\
\hline Свинина, $\mathrm{n}=12$ & 3 & Наявність рожевого кольору & 9 & Відсутність рожевого кольору \\
Яловичина, $\mathrm{n}=10$ & 4 & Наявність рожевого кольору & 6 & Відсутність рожевого кольору \\
Баранина, $\mathrm{n}=5$ & 1 & Наявність рожевого кольору & 4 & Відсутність рожевого кольору \\
Козлятина, $\mathrm{n}=4$ & 4 & Наявність рожевого кольору & & Відсутність рожевого кольору \\
Тушки птиці, $\mathrm{n}=11$ & 9 & Наявність рожевого кольору $\mathrm{n}=6$ & 2 & Відсутність рожевого кольору $\mathrm{n}=1$ \\
\hline
\end{tabular}

Проведеними дослідженнями встановлено, що найбільша кількість тушок птиці була оброблена оцтовою кислотою, визначалася за інтенсивністю рожевого кольору м'яса.

Суть методу визначення оброблення м'яса забійних ссавців та птиці за калію перманганатом полягає у встановленні наявності або відсутності слабо- рожевого кольору 3 додаванням розчину сірчаної кислоти 3 масовою концентрацією 0,5 моль/дм ${ }^{3}$ у кількості 0,4-0,5 $\mathrm{cm}^{3}$.

Завдання розробленого експрес-методу вирішувалася тим, що на поверхню свинини, яловичини, баранини, козлятини та на тушку птиці площею розміром $2,0 \times 2,5$ см наносили градуйованою піпеткою 0,4- 
0,5 $\mathrm{cm}^{3}$ розчину сірчаної кислоти 3 масовою концентрацією 0,5 моль/дм ${ }^{3}$ і через $0,5-1$ хвилину встановлювали наявність або відсутність слабо-рожевого кольоpy.

Розроблені експрес-методи визначення обробки м'яса забійних ссавців та птиці формаліном, хлором, пероксидом водню, оцтовою кислотою, калієм перманганатом є простими у виконанні, а їх результати дають конкретні якісні показники. Тому дані експресметоди пропонуються нами поряд з іншими методами визначення якості та безпечності м'яса забійних ссавців і птиці (визначення органолептики, вмісту аміноаміачного азоту, сірководню, аміаку, величини $p H$ тощо). Ці методи можна використовувати для визначення безпечності та якості м'яса забійних ссавців і птиці під час зберігання та реалізації у виробничих лабораторіях на потужностях 3 переробки м'яса, супермаркетах, оптових базах, у державних лабораторіях ветеринарної медицини, в лабораторіях ветеринарно-санітарної експертизи на агропромислових ринках, а також під час проведення судової експертизи харчових продуктів, зокрема м'яса забійних ссавців та птиці.

\section{Висновки}

1. Розроблені експрес-методи визначення безпечності м'яса забійних ссавців та птиці за їх оброблення формаліном, хлором, пероксидом водню, оцтовою кислотою, калієм перманганатом мають достовірність показників у межах від 99,4 до 99,9\%.

2. Для контролю якості й безпечності м'яса забійних ссавців та птиці під час їх зберігання й реалізації пропонується застосовувати розроблені експресметоди у виробничих лабораторіях потужностей із переробки м'яса, забійних підприємствах та підприємствах із реалізації та зберігання м'яса, у державних лабораторіях ветеринарної медицини та в лабораторіях ветеринарно-санітарної експертизи на агропродовольчих ринках, а також під час проведення судової експертизи харчових продуктів, зокрема м'яса забійних ссавців та птиці.

Перспективою подальших досліджень буде розроблення методів виявлення заміни складників м'ясних продуктів нерецептурними складниками.

\section{References}

Pro veterynarnu medytsynu (2002). Zakon Ukrainy. Verkhovna Rada Ukrainy. Ofits. Vyd. K.: Parlam. vyd-vo http://zakon.rada.gov.ua/laws/show/2498-12 (in Ukrainian).
Pro osnovni pryntsypy ta vymohy do bezpechnosti ta yakosti kharchovykh produktiv (2014). Zakon Ukrainy. Verkhovna Rada Ukrainy № 1602-VII vid 22.07.2014r. Ofits. Vyd. K.: Parlam. vyd-vo. http://zakon.rada.gov.ua/laws/show/771/97-вp (in Ukrainian).

Rehlament (IeS) № 854/2004. Yevropeiskoho Parlamentu i Rady vid 24 kvitnia 2004 r. shchodo vyznachennia osobly-vykh pravyl, shcho stosuiutsia orhanizatsii ofitsiinoho kontroliu po vidnoshenniu do produktiv ssavtsivnoho pokho-dzhennia, pryznachenykh dlia spozhyvannia liudynoiu (Ofitsiinyi visnyk YeS L 139 vid 30.04.2004 r.) http://zakon.rada.gov.ua/laws/ show/994_a67 (in Ukrainian).

Rehlament (IeS) № 852/2004. YeS Yevropeiskoho parlamentu i Rady vid 29.04. 2004 r. Pro hihiienu kharchovykh produktiv. https://www.fsvps.ru/fsvpsdocs/ru/laws/eu/852-2004.pdf (in Ukrainian).

Systemy upravlinnia bezpechnistiu kharchovykh produktiv (2007). Vymohy do bud-yakykh orhanizatsii kharchovoho lantsiuha: DSTU ISO 22000:2007 (ISO 22000:2005, IDT). K.: Derzhspozhyvstandart, 31 (in Ukrainian).

Reichert, J.E. (2006). Possible methods of automatic on leni determination of quality parameters when classifying and selecting carcasses and meat cuts. Fleischwirtschaft International, 4, 2-4.

Page, J.K., Wulf, D.M., \& Schwotzer, T.R. (2001). A survey of beef color and pH. J. Animal Science, 79(3), 678-687. https://www.ncbi.nlm.nih.gov/pubmed/11263828.

Bohatko, N.M., Bukalova, N.V., \& Melnyk, A.Iu. (2015). Vyznachennia falsyfikatsii miasa zabiinykh ssavtsiv ta ptytsi pry zastosuvanni ekspres-metodu. Nauk. Visnyk Lvivskoho nats. un-tu vet. medytsyny ta biotekhnolohii imeni S.Z. Hzhytskoho. Seriia "Veterynarni nauky", 17, 1(61), 199-204. http://nbuv.gov.ua/UJRN/nvlnu_2015_17_1\%282\%29 42 (in Ukrainian).

Mjaso (1979). Metody otbora prob obrazcov i organolepticheskie metody opredelenija svezhesti: GOST 7269-79. M.: Gosstandart (in Russian).

Mjaso (1978). Metody himicheskogo i mikroskopicheskogo analiza svezhesti mjasa: GOST 23392-78. M.: Gosstandart (in Russian).

Pravyla peredzabiinoho veterynarnoho ohliadu tvaryn i veterynarno-sanitarnoi ekspertyzy miasa ta miasoproduktiv. Zatverdzheni nakazom Holovy Derzhdepartamentu veterynarnoi medytsyny za № 28 vid 7.06. 2002 r. ta zareiestrovani v Miniusti yustytsii Ukrainy 21.06.2002 r. za № 524/6812 (in Ukrainian). 